\title{
Keadilan Dalam Bisnis Gadai
}

\author{
Naomi Sampe \\ Sekolah Tinggi Agama Kristen Negeri Toraja \\ naomisampe23@gmail.com
}

\begin{abstract}
The habit of debit and credit has become tradition in human culture as far back as. The system of debit and credit also happened in outgrowth. In hundreds years, it expand from barter system in primitive society towards variety methods, until now. There are many ways for people to get loans, and morover in easier manner. The commonly way in taking the allowance is by using bailed out. Thats why,nowdays there so many institution or person pop out to offer a term loan, such as bank, cooperative (enterprise) that emerge in saving and loan, credit union, financing instituion, loan office, and even moneylender. This research is needed to help emerge any understanding into some problem solving on how the christian ethics addressing the alternatives to face this problem of pawning.
\end{abstract}

Keywords: the business ethic, fiduciary, pawn, justness, salaries and wages, social, economic distrubution

Abstrak: Budaya utang piutang telah menjadi tradisi dalam masyarakat sejak dahulu. Sistem transaksi utang piutang juga mengalami perkembangan. Dari sistem barter dalam masyarakat primitif sederhana, berkembang melalui ratusan tahun menjadi berbagai macam cara hingga saat ini. Cara-cara yang dapat ditempuh untuk mendapatkan pinjaman saat ini beragam dan semakin mudah metodenya. Yang paling umum dilakukan adalah mengambil kredit dengan memberikan jaminan. Lantas, bermunculanlah berbagai lembaga/orang yang dapat memberikan pinjaman dengan bunga yang disepakati, seperti bank, koperasi simpan pinjam, credit union, lembaga finance dan pegadaian bahkan rentenir dengan resiko masing-masing. Masalah ini memerlukan kajian penelitian untuk memberi pandangan etis kristiani sebagai salah satu alternatif teologi menghadapi persolan bisnis gadai ini.

Kata-kata kunci: etika bisnis, sistem gadai, keadilan, laba, sosial, distribusi ekonomi.

\section{A. Pendahuluan}

Bisnis gadai merupakan suatu budaya ekonomi kerakyatan dari berbagai daerah di Nusantara. Masyarakat menggadaikan barang-barang berharga dan tanah untuk memperoleh pinjaman sementara. Konsep gadai tanah yang terjadi di Indonesia berbeda dengan sejarah pegadaian yang disahkan oleh pemerintah. Sebelum datangnya Belanda dan para penjajah lainnya ke Indonesia, masyarakat Indonesia terbiasa melakukan gadai tanah. Secara sosial kultural, masyarakat Indonesia sudah lazim melakukan transaksi hutang piutang dengan menggunakan jaminan tanah milik. Penelitian tentang gadai yang sudah ada sebelumnya dikaji oleh Sulaeman Jajuli dalam bukunya berjudul: Kepastian Hukum Gadai Tanah dalam Islam. 
Dalam penelitian ini, topik kajian adalah keadilan gadai tradisional yang masih primitif dan sederhana, kemudian secara metodik, sudut pandang yang digunakan adalah etika Kristen dengan obyek penelitian orang Kristen tradisional yang pernah atau sedang melakukan gadai tradisional.

Dari perspektif etika Kristen, masalah bisnis sering menimbulkan polemik. Problem etika yang mencuat dalam melaksanakan bisnis antara lain seberapa besar keuntungan yang layak diperoleh, metode pemasaran seperti apa yang tidak membohongi atau membodohi konsumen? Bagaimana seyogianya perjanjian bisnis yang adil penting untuk dijelaskan kepada umat, namun perbedaan penafsiran tetap tidak terhindarkan. Secara khusus dalam bisnis gadai, bagaimana transaksi yang adil antara pegadai dan penggadai? Persoalan-persoalan inilah yang penulis akan urai dalam tulisan ini, agar dapat membantu menunjukkan beberapa alternatif sikap etik demi membantu dalam pengambilan keputusan.

\section{B. Sistem Gadai}

Gadai merupakan sebentuk usaha pinjam meminjam uang dengan jangka waktu tertentu, dimana pegadai menyerahkan barang sebagai tanggungan kepada penggadai. Lalu, jika sampai pada waktunya tidak ditebus, maka status barang itu berubah menjadi hak pihak pemberi pinjaman. Gadai dapat pula diartikan sebagai barang yang diserahkan sebagai tanggungan utang. Kredit jangka pendek dengan tanggungan sekuritas biasanya berlaku tiga bulan dan dapat diperpanjang apabila tidak dihentikan oleh salah satu pihak. Bergadai artinya meminjam uang dari seseorang atau lembaga dengan menyerahkan barang sebagai jaminan. Pada sisi lain, gadaian artinya barang yang digadaikan, sedang pegadai berarti orang yang bergadai, dan pegadaian adalah tempat bergadai atau rumah gadai. Yang terakhir penggadai adalah orang yang menggadaikan, sedang penggadaian bermakna proses penggadaian. ${ }^{1}$ Pegadaian berasal dari kata gadai, artinya barang yang dijaminkan saat meminjam uang pada lembaga atau seseorang. Bila pinjaman tidak dapat dikembalikan maka barang yang digadaikan akan menjadi hak milik tempat pegadaian. Kegiatan pokok pegadaian adalah memberikan pinjaman kepada masyarakat dengan jaminan suatu barang bergerak seperti perhiasan dan kendaraan; sedangkan jaminan barang tidak bergerak adalah rumah dan tanah. ${ }^{2}$ Dalam usaha gadai ini ada dua pihak yang menjalin kontrak bisnis yakni peminjam dan pemberi pinjaman dengna syarat adanya barang tanggungan yang dapat ditebus dalam jangka waktu tertentu.

Definisi lain dari istilah gadai yaitu sebentuk hak yang didapatkan oleh seseorang karena memberi piutang atas suatu barang. Hak tersebut diserahkan oleh orang yang berutang atau orang lain atas nama pemilik barang. Kemudian barang tersebut dikusai oleh orang/pihak berpiutang yang kemudian berhak menerima pembayaran sebagai pelunasan dari pinjaman atau barang tersebut.

Dalam konteks gadai tanah, terminologi gadai menurut Ensiklopedia Hukum Adat dan Budaya Indonesia, diartikan sebagai hubungan antara seseorang dengan benda berupa tanah kepunyaan orang lain yang berutang dalam bentuk uang kepadanya, selama utang tersebut belum dibayar maka benda berupa tanah tersebut

1 Tim Penyusun Kamus Pusat pengembangan Bahasa Indonesia, Departemen Pendidikan dan Kebudayaan, Kamus Besar Bahasa Indonsia (Jakarta: Balai Pustaka, 1998), 246-247.

2 Tri Astuti, Pedoman Umum Ekonomi (Jakarta: Lembar Langit Indonesia, 2014), 210. 
tetap berada dalam penguasaan pemegang gadai. ${ }^{3}$ Pada prinsipnya bisnis gadai masih berada dalam wilayah jual dan beli. Dalam pemahaman gadai sebagai transaksi jual beli, maka jual gadai bermakna penyerahan tanah dengan menerima bayaran berupa uang melalui perjanjian dan barang tersebut dapat ditebus kembali oleh pihak atau orang yang menjualgadaikan tanahnya. ${ }^{4}$ Kata kunci memahami gadai ini adalah pada adanya prinsip perjanjian.

Hubungan gadai dapat juga tidak terikat pada waktu tertentu. Dalam hal ini gadaian dapat ditebus setiap waktu dan hak untuk menebus ini boleh berpindah turun kepada ahli-ahli waris dari si pemberi gadai jika si pemberi gadai belum mampu untuk menebus. Sementara itu jika perjanjian gadai terikat oleh waktu tertentu maka gadaian itu tidak boleh ditebus sebelum waktu yang telah disepakati pada waktu penggadaian itu dilakukan. Si pemberi gadai dapat menebus miliknya pada waktu yang telah disepakati. ${ }^{5}$

Dalam hal hak pakai atas barang dan tanah jika pemegang gadai pada suatu gadaian mendapatkan hak pakai atas barang (gadai-pakai), maka gadaian itu biasanya tidak disertai bunga gadai. Pada sisi lain jika jika tidak beserta hak pakai (gadai simpan) maka biasanya gadaian disertai bunga gadai, seperti yang berlaku pada lembanga-lembaga perkreditan dan rumah gadai. ${ }^{6}$ Ketidakmampuan seseorang membayar bunga gadai atau menebus barang tanggungan, telah membuat banyak orang harus kehilangan barang berharga tanah bahkan rumah. Di sinilah muncul persoalan etis yang pelik antara bisnis, keadilan dan perikemanusiaan dalam kaitan bisnis gadai modern.

\section{Budaya Gadai Tradisional}

Strategi ekonomi tradisional yang sangat mendasar diorganisir atas faktor kekerabatan dimulai dari keluarga, kerabat dan suku. Dalam masyarakat tradisional, penerapan strategi ekonomi ini lebih melekat pada unsur kekeluargaan karena sangat dirasakan bahwa pertanahan dan kelangsungan hidup keluarga tergantung sepenuhnya kepada pengadaan dan penerapan strategi ekonomi dalam lingkungan di mana mereka berdiam ${ }^{7}$. Jual gadai merupakan suatu perbuatan pemindahan hak atas tanah kepada pihak lain (yakni pribadi kodrat) yang dilakukan secara terang dan tunai sedemikian rupa sehingga pihak yang melakukan pemindahan punya hak untuk menebus kembali tanah tersebut. Oleh karena itu, pemindahan hak atas tanah pada jual gadai bersifat sementara, walaupun kadang-kadang tidak ada patokan yang tegas mengenai sifat sementara waktu tersebut. Ada kecendrungan untuk membedakan antara gadai biasa dengan gadai jangka waktu, dimana yang terakhir cenderung untuk memberikan semacam patokan pada sifat sementara dari perpindahan hak atas tanah tersebut. Pada gadai biasa, maka tanah dapat ditebus oleh penggadai setiap saat. Pembatasannya adalah satu tahun panen, atau apabila di atas tanah masih terdapat tumbuh-tumbuhan yang belum dipetik hasil-hasilnya. Dalam hal ini, maka penerima gadai tidak berhak untuk menuntut, agar penggadai menebus tanahnya 1997), 57.

${ }^{3}$ Hilman Hadikusuma, Ensiklopedi Hukum Adat dan Adat Budaya Indonesia (Bandung: Alumni,

${ }^{4}$ Sulaeman Jajuli, Kepastian Hukum Gadai Tanah dalam Islam (Yogyakarta: Penerbit Deepublish: 2015), 75.

${ }^{5}$ Roelof Van Dijk, Pengantar Hukum Adat Indonesia (University California, 2011), 61.

${ }^{6}$ Ibid., 66.

${ }^{7}$ Yakob Tomatala, Antropologi, Dasar Pendekatan Pelayanan Lintas Budaya (Jakarta: Media Penerbit Kristen YT Leadership foundation, 2007), 206. 
pada suatu waktu tertentu. Untuk melindungi kepentingan penerima gadai, maka dia dapat melakukan paling sedikit dua tindakan, yakni :

a. Menganak gadaikan (onderverpanden) di mana penerima gadai menggadaikan tanah tersebut kepada pihak ketiga. Dalam hal ini terjadi dua hubungan gadai, yakni pertama antara penggadai pertama dengan penerima gadai pertama, dan kedua antara penggadai kedua (yang merupakan penerima gadai pertama) dengan pihak ketiga (sebagai penerima gadai kedua).

b. Memindah gadaikan (doorverpanden), yakni suatu tindakan dimana penerima gadai menggadaikan tanah kepada pihak ketiga, dan pihak ketiga tersebut menggantikan kedudukan sebagai penerima gadai untuk selanjutnya berhubungan langsung dengan penggadai. Dengan demikian, maka setelah terjadi pemindahan gadai, maka hanya terdapat hubungan antara penggadai dengan penerima gadai yang baru. ${ }^{8}$

Pada gadai jangka waktu, biasanya terdapat pembedaan antara gadai jangka waktu larang tebus dengan gadai jangka waktu wajib tebus. Perbedaan yang dimaksud adalah: Gadai jangka waktu larang tebus terjadi apabila antara penggadai dengan penerima gadai ditentukan, bahwa untuk jangka waktu tertentu penggadai dilarang untuk menebus tanahnya. Dengan demikian, apabila jangka waktu tersebut telah lalu, maka gadai ini menjadi gadai biasa. Sedangkan, gadai jangka waktu wajib tebus, yakni gadai dimana oleh penggadai dan penerima gadai ditentukan, bahwa setelah jangka waktu tertentu, tanah harus ditebus oleh penggadai. Jikalau tanah tersebut tidak ditebus, maka hilanglah hak penggadai atas tanahnya, sehingga statusnya berubah menjadi jual lepas. ${ }^{9}$

Adapun sistem gadai yang terjadi di dalam lingkungan Pegadaian juga memiliki perbedaan tersendiri dibandingkan gadai yang ada pada hukum adat. Dalam hal ini, gadai yang ada di Pegadaian menaruh objek gadainya hanya pada barang bergerak saja, yakni barang yang berwujud, dapat berpindah atau dipindahkan dari satu tempat ke tempat yang lain. Dan secara adminstrasi, gadai yang ada di Pegadaian memiliki suatu aturan yang tertulis, paten serta seragam, juga dilengkapi berbagai persyaratan serta ketentuan-ketentuan tentang perjanjian yang ditetapkan terlebih dahulu oleh pihak Pegadaian. Sedangkan praktik gadai yang ada dalam hukum adat, melihat objek gadainya buka hanya pada barang bergerak saja, namun juga bisa berupa tanah, rumah, tanah beserta rumah yang ada di atasnya dan barang-barang tidak bergerak lainnya. Lantas tidak ditemukan adanya sistem adminstrasi yang baku, juga tidak ada prasyarat tertulis yang ditetapkan terlebih dahulu.

\section{Etika Bisnis}

1. Keadilan dalam bisnis

Transaksi yang baik dan benar dalam proses jual beli atau gadai-menggadai harus memenuhi rasa keadilan bagi kedua belah pihak. Pandangan mengenai keadilan yang mewariskan pengaruh kuat adalah Aristoteles, ia membagi keadilan menjadi tiga bagian, yaitu: Keadilan Legal, yang menyangkut hubungan antara individu atau kelompok masyarakat dengan Negara. Intinya adalah semua orang atau kelompok masyarakat diperlakukan secara sama oleh negara di hadapan dan berdasarkan hukum yang berlaku. Keadilan Komutatif yang mengatur hubungan yang adil atau fair antara orang yang satu dengan yang lain atau warga negara yang satu dan warga negara lainnya. Maksudnya, keadilan legal lebih menyangkut hubungan 
vertikal antarwarga negara, keadilan komutatif menyangkut hubungan horizontal antara warga yang satu dan warga yang lain. Lalu, keadilan Distributif atau keadilan ekonomi, adalah distribusi ekonomi yang merata atau yang dianggap adil untuk semua warga negara. Jadi keadilan distributif bersangkut-paut pembagian kekayaan ekonomi termasuk hasil-hasil pembangunan. ${ }^{10}$

Sehubungan dengan keadilan, Adam Smith hanya menerima satu konsep atau teori keadilan yaitu, Keadilan Komutatif saja. Ia menolak keadilan distributif sebagai salah satu jenis keadilan oleh karena keadilan selalu menyangkut hak, sementara keadilan distributif justru tidak berkaitan dengan hak. Dalam buku etika bisnis yang ditulis Sonny Keraf, terdapat 3 prinsip pokok keadilan komutatif yang diambil dari gagasan Adam Smith, yakni:

a. Adanya Prinsip paling pokok dari keadilan yakni: prinsip no harm, atau prinsip yang tidak menimbulkan kerugian bagi pihak-pihak lain, secara konkrit tidak merugikan kepentingan dan hak orang lain. Pada dasarnya prinsip keadilan ini diadopsi dari dari kaidah emas yaitu: "Perlakukan orang lain sebagaimana anda ingin diperlakukan dan jangan lakukan pada orang lain apa yang anda sendiri tidak ingin dilakukan pada anda". Prinsip ini bukan hanya berlaku sebagai prinsip moral saja, melainkan juga menjiwai aturan hukum yang tertulis. Dengan demikian prinsip adil dalam bisnis mengukuhkan bahwa semua pihak atau relasi tidak boleh saling merugikan.

b. Selanjutnya, prinsip Non Intervention, artinya prinsip tidak ikut campur tangan. Prinsip ini menuntut agar demi jaminan dan penghargaan atas hak dan kepentingan tiap orang, tidak seorangpun diperkenankan untuk ikut campur tangan dalam kehidupan dan kegiatan orang lain. Campur tangan dalam berntuk apa pun akan berubah menjadi pelanggaran terhadap hak orang tertentu yang merupakan suatu (kerugian) dan itu berarti telah terjadi ketidakadilan. Dengan demikian, adanya campur tangan pemerintahpun akan dianggap sebagai pelanggaran keadilan. Sedapatdapatnya menihilkan intervensi pihak lain.

c. Kemudian prinsip keadilan tukar, yang berdasar pada prinsip nomor satu di atas. Sering dikenal sebagai prinsip pertukaran dagang yang fair, terutama terwujud dan terungkap dalam mekanisme harga dalam pasar. Menjadi jelas bahwa prinsip ini sesungguhnya merupakan implementasi lebih lanjut prinsip no harm secara khusus dalam pertukaran dagang antara satu pihak dengan pihak lain di dalam satu mekanisme pedagangan. ${ }^{11}$

Penjelasan lebih lanjut bagaimana prinsip keadilan tukar ini dapat terwujud, maka Adam Smith membuat perbedaan antara harga alamiah dan harga pasar atau harga aktual. Pertama-tama, harga alamiah adalah harga yang mencerminkan biaya produksi yang telah dikeluarkan oaleh produsen, yaitu terdiri dari tiga komponen biaya produksi berupa: upah buruh, keuntungan untuk pemilik modal, dan sewa (tanah, gedung, dan semacamnya). Dengan demikian, harga alamiah mengungkapkan biaya atau beban yang telah ditanggung oleh produsen dalam memproduksi barang tertentu. Lalu harga pasar atau harga aktual adalah harga yang aktual yang ditawarkan dan dibayar dalam transaksi dagang di dalam pasar. Jadi kalau suatu barang dijual dan dibeli pada tingkat harga alamiah, maka barang tersebut dijual dan dibeli pada tingkat harga yang adil. Oleh karena itu dapat dikatakan bahwa harga alamiah merupakan standar harga yang adil sebab pada pada level harga itulah para pelaku dagang sama-sama memperoleh laba.

${ }^{10}$ A. Sonny Keraf, Etika Bisnis: Tuntutan dan Relevansinya (Yogyakarta: Penerbit Kanisius, 1998), 138-142.

11 Ibid., 148-150. 
Pada pihak lain menurut Rawls, pasar bebas justru menimbulkan ketidakadilan. Karena setiap orang masuk dalam pasar bebas dengan bakat dan kemampuan alamiah yang berbeda-beda, peluang sama yang diberikan pasar tidak akan menguntungkan semua peserta. Sistem pasar yang memberi kebebasan yang sama itu justru membuka peluang bagi yang kuat memakan yang lemah, yang kaya menjadi semakin kaya, dan yang miskin semakin miskin. Pasar tidak adil dalam pemerataan ekonomi; Pasar, dengan kebebasan dan peluang yang sama bagi semua orang, justru hanya menguntungkan bagi yang berbakat, punya kemampuan, dan sudah kuat. Pasar sebaliknya tidak menguntungkan mereka yang lemah dan tidak berdaya. Will Kymlicka mengatakan: adalah tidak adil bila membiarkan mereka yang secara kodrati tidak beruntung mati kelaparan hanya karena mereka tidak punya sesuatu yang dapat ditawarkan kepada orang lain dalam sebuah pertukaran yang fair. Atas dasar ini John Rawls lalu mengajukan prinsip keadilan yang kedua, berupa prinsip perbedaan (difference principal) yaitu bahwa: ketidaksamaan sosial dan ekonomi harus diatur sedemikian rupa sehingga ketidaksamaan tersebut menguntungkan mereka yang paling kurang beruntung dan sesuai dengan tugas dan kedudukan yang terbuka bagi semua di bawah kondisi persamaan kesempatan yang sama. Dengan demikian jalan keluar utama untuk memecahkan ketidakadilan distribusi ekonomi oleh pasar adalah dengan mengatur sistem dan stuktur sosial agar terutama menguntungkan kelompok yang paling kurang beruntung. Sasaran pokok teori keadilan Rawls adalah: perubahan struktur sosial sedemikan rupa agar lebih menguntungkan kelompok yang kurang beruntung. Peran dan campur tangan pemerintah diizinkan untuk mengambil kebijaksanaan tertentu, termasuk malalui mekanisme pajak dalam rangka membantu kehidupan kelompok yang kurang beruntung. ${ }^{12}$

\section{Bisnis Bebas Nilai}

Menurut Adam Smith, sebagaimana yang dikutip Eka Darmaputera bahwa setiap orang berupaya untuk memperoleh keuntungan yang sebesar-besarnya dari apapun yang dimilikinya. Sesungguhnya, keuntungannya sendirilah yang ia pertimbangkan, bukannya keuntungan bagi masyarakat. Namun memperhitungkan keuntungan pribadi, dengan sendirinya akan membuat ia memilih apa yang paling menguntungkan bagi masyarakat luas. Dalam hal ini, seperti dalam hal-hal lain juga, ia dipimpin suatu tangan yang tidak kelihatan -invisible hand- yang membuat ia mengusahakan suatu tujuan, yang sebenarnya semula tidak dimaksudkannya. Maksud dari Adam Smith adalah: bahwa kecenderungan setiap orang untuk mencari keuntungan pribadi yang sebesar-besarnya tidak hanya merupakan kebenaran empiris belaka tetapi merupakan naluri yang menyatu dalam kodrat manusia Manusia tidak perlu membatasi kebebasan dan kecenderungan naluriahnya. Tanpa membatasi diri, manusia tetap akan terhindar dari malapetaka, oleh karena ada tangan yang tidak kelihatan. ${ }^{13}$

Ekonomi memunyai moralnya sendiri. Ia merupakan wilayah kehidupan manusia yang otonom yang berjalan menurut huum-hukumnya sendiri. Bila manusia berbuat sesuatu yang menguntungkan masyarakat, itu bukan suatu tindakan etis melainkan suatu mekanisme dalam system ekonomi itu sendiri. Ekonomi akan

12 K. Bertens, Pengantar Etika Bisnis (Yogyakarta: Kanisius, 2000), 101.

13 Eka Darmaputera, Etika Sederhana Untuk Semua: Bisnis, Ekonomi dan Penatalayanan (Jakarta: BPK Gunung Mulia, 1990), 20-21. 
berjalan dengan baik, apabila ia dibiarkan berjalan sesuai dengan kodratnya. Apabila ia dibiarkan bebas nilai14.

Namun pandangan di atas tidak sepenuhnya benar, bisnis tidak dapat dipisahkan dari nilai-nilai moral yang terkandung dalam masyarakat. Dalam bisnis selalu ada nilai manusiawi yang dipertaruhkan, oleh karena itu, bisnis perlu dilandasi oleh pertimbangan-pertimbangan etis. Dibutuhkan kesalingpercayaan antara: mitrabisnis, antara perusahaan dan karyawan, produsen dan konsumen. Selain itu, bisnis juga tidak bisa dilepaskan dari nilai etis dan norma-norma sosial.

\section{E. Tiga Teori Etika Dalam Bisnis}

Secara teoritik, berikut ini upaya mengonstruksi teori etika dalam bisnis dari pendekatan ahli etika, yakni Sonny Keraf; ${ }^{15}$ bahwa terdapat teori etika dalam bisnis, yakni: (1). Deontologis; Deontologis artinya pengetahuan tentang yang tentang keharusan atau kewajiban (Yun. Deon=wajib; logos=pegetahuan). Etika deontologis sering disebut etika kewajiban (yang berbicara benar-salah). Etika deontologis merupakan cara berpikir etis yang berpegang kuat pada prinsip, hukum, norma obyektif yang dianggap harus berlaku mutlak dalam situasi dan kondisi apapun juga. Prinsip-prinsip etika kewajiban berdasar pada kebaikan atau keburukan tindakan bukan pada akibatnya. Jadi metode perbuatan yang penting. (2). Teleologis atau etika akibat; telos = tujuan, akibat; logos = pengetahuan. Etika Teleologis tidak berpikir dalam kategori benar dan salah tetapi berpikir dalam kategori baik dan jahat. Dalam etika teleologis, kehendak Tuhan dinyatakan dalam maksud-Nya, rencana-Nya dan tujuan-Nya. (3). Utilitarianisme, Kriteria utamanya adalah: Manfaat, yaitu: bahwa kebijaksanaan atau tindakan itu mendatangkan manfaat atau kegunaan tertentu. Kriteria selanjutnya: manfaat terbesar, yaitu: bahwa kebijaksanaan atau tindakan itu mendatangkan manfaat terbesar (atau dalam situasi tertentu lebih besar) dibandingkan dengan kebijaksanaan atau tindakan alternatif lainnya. Jika kerugian tidak bisa dihindari maka tindakan yang menimbulkan kerugian terkecilah yang dianggap baik. Kriteria ketiga, menyangkut manfaat terbesar bagi sebanyak mungkin orang. Bila tidak bisa mengelak dari kerugian, maka kebijaksanaan atau tindakan itu dinilai baik kalau membawa kerugian yang sekecil mungkin bagi sesedikit mungkin orang. ${ }^{16}$

Kriteria yang sekaligus menjadi pengangan obyektif etika utilitarianisme adalah: manfaat terbesar bagi sebanyak mungkin orang. Secara padat, ketiga prinsip itu, dapat dirumuskan sebagai berikut: "bertindaklah sedemikan rupa, sehingga tindakanmu itu mendatangkan keuntungan sebesar mungkin bagi sebanyak mungkin orang." Nilai positif dari etika utilitarianisme, antara lain: Pertama, Nilai rasionalitasnya. Terlepas dari apakah agama atau Tuhan memerintahkan begini atau begitu, suatu tindakan atau kebijaksanaan dianggap baik kalau ia mendatangkan hal yang baik bagi manusia (kebahagiaan, kesehteraan, keuntungan dst.) Dasar atau alasan konkrit, mengapa suatu tindakan atau kebijaksanaan lebih baik dari yang lainnya adalah segi rasionalitasnya (masuk akal), bukan sekedar alasan metafisik mengenai perintah Tuhan atau agama. Kedua, Utilitarianisme sangat menghargai kebebasan setiap pelaku moral. Otonomi manusia diberi tempat sentral. Tidak ada paksaan bahwa orang harus bertindak sesuai dengan cara tertentu. Ketiga, Universalitasnya. Etika utilitarianisme, mengutamakan manfaat atau akibat, baik dari

14 Ibid.

${ }^{15}$ Keraf, Etika Bisnis, 23-27.

16 Ibid., 100-104. 
suatu tindakan bagi banyak orang, hal ini berbeda dengan etika teleologi lainnya yang terutama menekankan manfaat bagi diri sendiri atau kelompok sendiri.

\section{F. Prinsip Etika Bisnis Kristiani}

Dalam pemahaman etika bisnis, terdapat banyak prinsip yang diwarkan oleh para ahli eika maupun teolog. Dari sekian banyak prinsip tersebut penulis mengutip dan menyetujui beberapa prinsip umum etika bisnis dari Sonny Keraf, yang sesuai dengan etika Kristen. Prinsip-prinsip yang dimaksud adalah: Pertama, Prinsip Otonomi; yang dimaksud dengan prinsip ini adalah: sikap dan kemampuan seseorang untuk mengambil keputusan dan tindakan berdasar kesadaran yang otonom tentang apa yang diaggapnya baik untuk dilakukan. Yang disebut orang otonom adalah mereka yang sadar akan tidakannya, bebas dan bertanggungjawab atas tindakannya. Oleh karena itu, orang bisnis yang otonom yakni pebisnis yang sadar sepenuhnya mengenai kewajibannya dalam dunia bisnis ${ }^{17}$. Atau dengan perkataan lain, orang dengan prinsip otonom adalah mereka yang bebas tetapi bertanggungjawab dalam setiap keputusan bisnis yang diambilnya. Dalam prinsip etika Kristen, prinsip otonom ini diletakkan di bawah kehendak Tuhan. sehingga keputusan yang diambil sesuai dengan kehendak Tuhan (Kej. 41:16). Kedua, Prinsip kejujuran; prinsip ini amat penting dan sangat relevan dalam pemenuhan syarat-syarat perjanjian dan kontrak. Dan dibutuhkan dalam penawaran barang dan jasa dengan mutu dan harga setara, hal ini sangat penting untuk menjaga kepercayan konsumen. Dengan demikian pebisnis maupun perusahaan akan memperoleh kepercayaan dalam kerjasama dengan berbagai pihak. Dan kepercayaan adalah asset yang amat berharga dalam kegiatan bisnis ${ }^{18}$. Tanpa kejujuran maka bisnis akan mati (Ams. 11:11). Ketiga, Prinsip keadilan: dalam prinsip ini setiap orang harus diperlakukan sesuai aturan yang adil, rasional, obyektif, dan dapat dipertanggungjawabkan. Tidak boleh ada pihak yang dirugikan. ${ }^{19}$ Semua pihak yang terlibat harus mendapatkan keuntungan yang setara dan adil (Mi.6:8). Keempat, Prinsip saling menguntungkan; dalam hal ini, setiap pebisnis ditutut agar dapat menjalankan bisnis sedemikian rupa agar menguntungkan semua pihak terkait. Dalam dunia sekarang, prinsip in dikenal dengan istilah win win situation. ${ }^{20}$ Prinsip ini sangat alkitabiah, karena Allah menginkan keuntungan bagi semua (1Kor.10:24). Kelima, Prinsip integritas moral; prinsip ini bersifat internal dalam diri pelaku bisnis sendiri. seorang pebisnis dituntut untuk melaksanakan bisnis dengan moralitas yang tinggi untuk menjaga nama baiknya maupun nama baik perusahaannya. ${ }^{21}$ Seperti kata Amsal: Nama baik lebih berharga daripada harta yang banyak; dikasihi orang lebih baik daripada diberi perak dan emas. (Ams.22:1). Apabila nama baik hancur maka hilang pulalah peluang bisnis, dengan demikian, pelan tapi pasti harta kekayaan bahkan emas perak pun akan hilang.

\section{G. Laba}

Masalah batas-batas yang pasti dari keuntungan yang wajar, sangat rumit dan sulit untuk ditentukan. Namun demikian, secara kristiani ada beberapa hal yang dapat dijadikan acuan sekaitan dengan penetapaan harga maupun keuntungan yang

\footnotetext{
17 Ibid., 74.

18 Ibid., 77.

19 Ibid., 79.

20 Ibid.

21 Ibid.
} 
wajar. Hal-hal yang dimaksud adalah sebagai berikut: (1) Si penjual berhak memperoleh keuntungan dari usahanya. Sebaliknya si pembeli juga memunyai kewajiwan untuk memberikan kompensasi bagi jasa atau barang yang ia telah terima dari si penjual. Asas kepantasan atau kewajaran yang disesuaikan daya beli konsumen serta sesuai usaha tambahan yang telah dikeluarkan si penjual. Dalam Matius 25:16 secara tersirat digambarkan bahwa keuntungan merupakan sesuatu yang harus diterima oleh seseorang dalam usaha bisnis yang dilakukannya. Itu adalah haknya. (2) Laba atau keuntungan yang diperoleh tersebut, dimaksudkan agar si penjual dapat memperoleh nafkah untuk kebutuhan hidupnya (Kis. 18:3), dan dalam rangka mengembangkan usahanya (Yak. 4:13-14a). Sehingga ia dapat melakukan pelayanannya terhadap para pembeli secara berkesinambungan. Dalam hal ini perlu dingat dengan tegas bahwa laba diperoleh adalah cukup untuk melanjutkan usaha serta memenuhi kebutuhan hidup. Jadi tidak diperkenankan adanya keserakahan/ tamak, karena keuntungan yang diperoleh karena keserakahan bukanlah keuntungan yang wajar. (3) Yang dimaksudkan dengan keuntungan yang wajar adalah keuntungan yang dapat diperoleh si penjual, tanpa mengeksploitasi kebutuhan si pembeli. Artinya: "kesempatan" pihak pembeli tidak dieksploitasi sebagai kesempatan untuk mengeruk keuntungan yang berlebihan bagi penjual. ${ }^{22}$ Sebagai contoh ketika BBM langka, maka si penjual harus tetap menjual BBM sesuai harga standar. Profit yang wajar dalam hal ini tidak bersifat mengeksploitasi, atau dengan kata lain, menguntungkan si penjual, namun juga tetap menyisakan daya beli konsumen.

Pada akhirnya ada tidaknya patokan yang pasti mengenai harga barang dan jasa, tetapi tergantung kepada keputusan etis yang harus diambil oleh si penjual secara pribadi. Yang perlu ditanyakan secara timbal balik ialah: apakah keuntungan yang ia peroleh itu, merugikan dan mengorbankan orang lain, ataukah keuntungan yang ia peroleh sudah melalui suatu transaksi yang saling menguntungkan keduabelah pihak (penjual dan pembeli).

\section{H. Etika Bisnis Kristiani Tentang Gadai}

Kisah penciptaan memberi acuan bagi orang Kristen tentang norma dasar ekonomi bahwa hanya Allah yang patut disembah dan dilayani oleh segenap hidup manusia, bahwa manusia diberi makna hidup yang sangat mulia oleh Allah, bahwa panggilan hidup manusia sebagai gambar Allah yang mulia itu adalah menjadi hamba Allah, bahwa alam dan segenap potensinya boleh diterima dan dikelola dengan penuh syukur oleh manusia, dan bahwa kekayaan alam atau pun kekayaan hasil dari tindak kreatif manusia mengelola alam itu bukan milik mutlak manusia tetapi milik Allah, sehingga tidak boleh diberi tempat pemutlakan di dalam keberadaan manusia. Tidak ada tempat bagi kehidupan ekonomi yang egosentris, yang serakah, atau yang kebalikannya yaitu merendahkan benda dalam hidup bertarak, atau sikap tidak ilmiah yang melumpuhkan kehidupan ekonomi karena pantang menjamah alam dan materi yang dianggap suci ilahi, tidak demikian sikap kristiani.

Teks Alkitab menunjukkan hukum-hukum ibadah di Kitab Imamat, dalam bentuk aturan-aturan tentang bagaimana umat Allah harus memperlakukan sesamanya, pekerja-pekerjanya, institusi-institusi hukum dan peradilannya, tanah, binatang-binatang dan harta miliknya, hari kerja dan hari istirahatnya, hutang piutang, dlsb. Dalam hal gadai-menggadai Alkitab dengan tegas menyatakan bahwa

22 Eka Darmaputera, Etika Sederhana Untuk Semua, 119-120. 
transaksi gadai harus dilandasi dengan kasih. Peraturan tentang gadai, diuraikan dengan jelas dalam Keluaran 24:6-17:

"Janganlah mengambil kilangan atau batu kilangan atas sebagai gadai, karena yang demikian itu mengambil nyawa orang sebagai gadai. ... Apabila engkau meminjamkan sesuatu kepada sesamamu, janganlah engkau masuk ke rumahnya untuk mengambil gadai dari padanya. Haruslah engkau tinggal berdiri di luar, dan orang yang kauberi pinjaman itu haruslah membawa gadai itu ke luar kepadamu. ... Jika ia seorang miskin, janganlah engkau tidur dengan barang gadaiannya; kembalikanlah gadaian itu kepadanya pada waktu matahari terbenam, supaya ia dapat tidur dengan memakai kainnya sendiri dan memberkati engkau. Maka engkau akan menjadi benar di hadapan TUHAN, Allahmu. ... Janganlah engkau memperkosa hak orang asing dan anak yatim; juga janganlah engkau mengambil pakaian seorang janda menjadi gadai

Belas kasih pada sesama manusia disini tidak terdiri dari perasaan-emosi dangkal saja, melainkan tindakan yang berdasar keinsafan bahwa setiap manusia berutang-nyawa pada Tuhan. Etika yang pantas untuk membayar utang itu ialah dengan meneruskan perhatian dan kasih dari Tuhan kepada orang lain dalam kesadaran bahwa semuanya bersumber dari Tuhan. Pelepas uang dilarang untuk mengambil bunga dari sesama bila pinjaman tersebut untuk keadaan darurat (Kel.22:25). Lain halnya jika pinjaman itu untuk modal usaha. Sementara itu untuk pengambilan barang gadai harus dilakukan sedemikian, sehingga tidak menambah beban penderitaan si miskin, dan tidak menurunkan harkatnya sebagai sesame warga masyarakat dan sesama manusia. ${ }^{23}$ Pada sisi lain Tuhan melarang keras umat-Nya mengeksploitasi kesulitan dan kemiskinan orang lain untuk menimbun harta bagi dirinya.

Karena dengan sewenang-wenang engkau menerima gadai dari saudara-saudaramu, dan merampas pakaian orang-orang yang melarat; ..... Keledai kepunyaan yatim piatu dilarikannya, dan lembu betina kepunyaan seorang janda diterimanya sebagai gadai, ...... Ada yang merebut anak piatu dari susu ibunya dan menerima bayi orang miskin sebagai gadai (Ayb. 22:26, 24:3,9).

Hak milik pribadi dan keberlanjutan aset mata pencaharian dalam sebuah keluarga juga diperhatikan dalam Firman Tuhan. Mencolok tekanan pada upaya perlindungan terhadap hak keluarga atas warisan. Apabila seseorang jatuh miskin dan terpaksa menjual (menggadai) warisannya, maka salah seorang kerabatnya mempunyai hak untuk menebusnya (Im. 25:25-28). Hal ini dimaksudkan, agar warisan itu sedapat mungkin tetap beradadi lingkungan keluarga. Bukan hanya mengenai warisan. Seorang yang jatuh miskin, namun kemudian berkecukupan lagi, mempunyai hak untuk membeli kembali milik yang pernah dijualnya. Dan kalaupun ia tidak mampu menebusnya, miliknya itu baru dapat dijual oleh yang memegangnya setelah jangka waktu tertentu. ${ }^{24}$ Demikianlah sedapat mungkin dicegah kemungkinan orang-orang kaya mempergunakan kesempatan untuk menindas dan memanfaatkan kesulitan atau kemiskinan orang lain untuk keserakahannya.

Alkitab, iman dan norma perilaku orang Kristen berawal dengan pengakuan bahwa Allah adalah Pencipta segala sesuatu. Pengakuan iman ini berarti bahwa Allah adalah sumber, penguasa, dan pemilik satu-satunya dari segala sesuatu (Kej. 1 dan 2). Oleh karena itu tidak ada satu sector pun dalam dimensi kehidupan manusia yang dapat mengklaim otonomi penuh bagi dirinya, termasuk tata ekonomi dan lebih

23 D.I.J. Cairns, Tafsiran Alkitab Ulangan 2 (Jakarta: BPK Gunung Mulia, 1986), 208.

${ }^{24}$ Eka Darmaputera, Etika Sederhana Untuk Semua, 57. 
khusus lagi system gadai dan utang piutang. Ekonomi berfungsi untuk melayani dan mewujudkan kehendak Tuhan; bertujuan untuk kemuliaan Allah dan kesejahteraan penuh setiap dan seluruh ciptaannya.

Seluruh ciptaan Allah termasuk dunia material disediakan Bapa bagi kebutuhan semua anak-anak-Nya bukan cuma untuk sebagian orang. Untuk itu diperlukan kerja keras dalam mengolahnya. Dalam II Tes. 3:10 ia difirmankan jika seorang tidak mau bekerja janganlah ia makan. "Aturan ini berlaku bagi orang-orang yang memilih untuk tidak bekerja, yang terlalu malas, terlalu rewel memilih atau terlalu tidak bisa diandalkan untuk memegang pekerjaan. Ayat 14 melanjutkan bahwa: kita tidak boleh bergaul dengan orang yang menolak untuk bekerja dan menjadi benalu bagi masyarakat"25.

Pelajaran yang dapat menjadi prinsip di sini adalah bahwa kemilikan, kerja, hidup sangat berharga karena berasal dari Allah. Karena itu manusia yang merdeka adalah manusia yang menghormati Allah, menghormati kemilikan dirinya dan sesamanya, mengisi hidup berekonomi dalam suasana syukur dan penuh sikap murah hati. Visi ekonomi bukan visi sosialisme atau kapitalisme, tetapi visi ekonomi yang kudus adalah menghargai kepemilikan mutlak Allah, mensyukuri setiap pemberian Allah dalam sikap penatalayanan, dan ekonomi yang bergerak maju di dalam keadilan, kebenaran, kesucian, kebersyukuran, kepedulian dan kemurahan hati. Nilai dalam visi ini menjadi standard nilai etika bisnis kristiani.esus tidak mengidealisasikan kemiskinan maupun kekayaan, melainkan kecukupan dan kesederhanaan, atau yang dikenal dengan spiritualitas keugaharian. Yesus mengecam ketamakan, sebab ketamakan adalah pencermian dari sikap yang menjadikan kekayaan sebagai tujuan hidup dan mempertuhankan harta dengan menjadikan sesama sebagai objek untuk diperas dan diperah bagi kekayaan pribadi. ${ }^{26}$ Acapkali, orang miskinpun rakus, sama seperti para kapitalis; oleh karena itu, sorotan Yesus bukan pada sedikit atau banyaknya kekayaan, tetapi pada pengecaman tamak atau apakah ada pengutamaan kasih.

Umat Perjanjian Baru itu adalah bagian dari Kerajaan Allah, orang-orang yang menikmati berlakunya pemerintahan Allah yang memerdekakan, yang membuat mereka menikmati hidup seutuhnya sepenuhnya, mensyukuri setiap pemberian Allah dalam sikap murah hati, menatalayan, dan karena itu tidak terikat melainkan merdeka. Di dalam Yesus, Ekonomi Allah memungkinkan ekonomi manusia tidak menjadi perhambaan materi, pemberhalaan hartabenda, perbudakan keserakahan, melainkan merdeka penuh syukur, kesemarakan yang saling menumbuhkan dan yang menyukakan hati Allah.

Setiap manusia bertanggungjawab mengembangkan talenta yang dipercayakan kepadanya oleh Sang Pemilik segalanya. Tanggungjawab menata dan menggunakan harta tersebut dilaksanakan dengan penuh ketaatan dan kesetiaan pada kehendak Tuhan. Segala tindak tanduk dan motivasi dalam berbisnis berada dalam pengawasan Tuhan dan menentukan keberhasilan seseorang sebagai orang kepercayaan Tuhan.

25 Jerry dan Mary White, Pemahaman Kristen Tentang Bekerja, Arti, Tujuan dan Masalahmasalahnya (Jakarta: BPK Gunung Mulia 1997), 21.

${ }^{26}$ Eka Darmaputera, Pergulatan Kehadiran Kristen di Indonesia (Jakarta: BPK Gunung Mulia: 2001), 708-709. 


\section{Daftar Pustaka}

Astuti, Tri. Pedoman Umum Ekonomi. Jakarta: Lembar Langit Indonesia, 2014.

Bertens, K. Pengantar Etika Bisnis. Yogyakarta: Kanisius, 2000.

Darmaputera, Eka. Etika Sederhana Untuk Semua: Bisnis, Ekonomi. Jakarta: BPK Gunung Mulia, 1990. . Pergulatan Kehadiran Kristen di Indonesia. Jakarta: BPK Gunung Mulia, 2001.

Dijk, Roelof Van. Pengantar Hukum Adat Indonesia. University California, 2014.

Hadikusuma, Hilman. Ensiklopedi Hukum Adat dan Adat Budaya Indonesia. Bandung: Alumni, 1997.

Jajuli, Sulaeman. Kepastian Hukum Gadai Tanah dalam Islam. Yogyakarta: Penerbit Deepublish, 2015.

Jerry dan Mary White. Pemahaman Kristen Tentang Bekerja, Arti, Tujuan dan Masalahmasalahnya. Jakarta: BPK Gunung Mulia, 1997.

Keraf, A. Sonny. Etika Bisnis: Tuntutan dan Relevansinya. Yogyakarta: Penerbit Kanisius, 1998.

Ragawino, Bega, Pengantar dan Asas-asas Hukum Adat. Universitas Padjadjaran. 2012

Sanderan, Rannu. Dilema Kepemilikan Tanah Adat. Penelitian Reguler., STAKN Toraja, 2017.

Tim Penyusun Kamus Pusat Pengembangan Bahasa Indonesia Departemen Pendidikan dan Kebudayaan, Kamus Besar Bahasa Indonesia. Jakarta: Balai Pustaka, 1998.

Tomatala, Yakob. Antropologi, Dasar Pendekatan Pelayanan Lintas Budaya. Jakarta: Media Penerbit Kristen YT Leadership foundation, 2007. 